\title{
$D_{2} \cdot 1708$
}

\section{Wall Power Measurements of Impurity Radiation in ORMAK}

\author{
C. E. Bush \\ J. F. Lyon
}




\section{DISCLAIMER}

This report was prepared as an account of work sponsored by an agency of the United States Government. Neither the United States Government nor any agency Thereof, nor any of their employees, makes any warranty, express or implied, or assumes any legal liability or responsibility for the accuracy, completeness, or usefulness of any information, apparatus, product, or process disclosed, or represents that its use would not infringe privately owned rights. Reference herein to any specific commercial product, process, or service by trade name, trademark, manufacturer, or otherwise does not necessarily constitute or imply its endorsement, recommendation, or favoring by the United States Government or any agency thereof. The views and opinions of authors expressed herein do not necessarily state or reflect those of the United States Government or any agency thereof. 


\section{DISCLAIMER}

Portions of this document may be illegible in electronic image products. Images are produced from the best available original document. 
Primlen in the IInited States of Amcrica. Available fium National Technical Information Service

U.S. Department of Commerce 5285 Port Royal Road, Springfield, Virginia 22161

Price: Printed Copy $\$ 4.50$; Microfiche $\$ 3.00$

This report was prepared as an account of work sponsored by an agency of the United States Government. Neither the United States Government nor any agency thereof, nor any of their employees, contractors, subcontractors, or their employees, makes any warranty, express or implied, nor assumes any legal liability or responsibility for any third party's use or the results of such use of any information, apparatus, product or pron.ess disclosed in this report, nor iepresents that its use by such third party would not infringe privately owned rights. 
ORNL/TM- 6148

Dist. Category UC-20f

Contract No. W-7405-eng-26

Fusion Energy Division

WALL POWER MEASUREMENTS OF IMPURITY

RADIATION IN ORMAK

C. E. Bush and J. F. Lyon

Date Published - December 1977

This report was prepared as an account of work

Ourcuiment. Plaithat the

United States nor the United States Department of

Energy, nor any of theis employees, nor any of their

contractors, subcontractors, or their employees, makes

any watranty, express or implied, or assumes any legal

liability or responsibiity for the accuracy, completeness

or usefulness of any information, apparatus, product or

process disclosed, or represents that its use would not

infringe privately owned rights.

\section{Prepared by the}

OAK RIDGE NATIONAL LABORATORY

Oak Ridge, Tennessee 37830

operated by

UNION CARBIDE CORPORATION

for the

DEPARTMENT OF ENERGY 


\section{THIS PAGE}

\section{WAS INTENTIONALLY LEFT BLANK}




\section{CONTENTS}

$\underline{\text { Page }}$

ABSTRACT . . . . . . . . . . . . . . . . . . . . 1

1. INTRODUCTION . . . . . . . . . . . . . . . . 2

2. THE MEASUREMENT AND ITS INTERPRETATION . . . . . . . . . 3

3. STEADY-STATE WALL POWER SCALING . . . . . . . . . . 8

4. VARIATION OF WALL POWER WITH GAS PUFFING . . . . . . . . . . 12

5. TIME BEHAVIOR OF THE WALL POWER FLUX FOR UNSTABLE DISCHARGES • • 13

6. CONCLUSIONS ..................... 16 


\begin{abstract}
Time- and space-resolved measurements of the power loss to the liner of the Oak Ridge Tokamak (ORMAK) indicate that a large fraction ( $260 \%$ ) of the electron power input is lost to the wall, rather than to the limiter. This fraction is relatively constant over a wide range of Input powers (ohmic heating plus neutral beam injection) and plasma conditions and for most of the discharge duration. Most of this energy - loss is due to impurity radiation from an emission profile having a mean radius about a third that of the limiter radius and is time-correlated with gross plasma fluctuations, internal disruptions, and related spectroscopic impurity signals. In gas puffing experiments resulting in higher densities, the ratio of radiative power to the electron density continually falls as density increases during the course of the discharge.
\end{abstract}




\section{INTRODUCTION}

Impurity radiation is a substantial part of the electron energy loss in present tokamak experiments [1-4]. An accurate measurement of the magnitude, time behavior, and spatial distribution of the radiative energy loss is necessary in order to understand the electron energy losses in a tokamak and scaling of these losses with plasma parameters. Previous estimates of the impurity radiation loss have been based on summing over spectroscopic line intensities $[5,6]$ or on the total energy flux to the wall, inferred from bolometric measurements [7-10].

The technique we describe employs a pyroelectric detector $[11,12]$ which measures the instantaneous power incident on the detector rather than the accumulated incident energy. This permits both a more sensitive measurement of instantaneous power and a better time resolution than bolometric measurements with signal differentiation: Spatial information on the radiating volume is obtained by varying the radial position (and hence the acceptance angle) of the detector and comparing the signal amplitude variation obtained with that calculated for various radial distributions of the plasma radiation.

In the sections which follow, we describe (1) the physical basis of the measurement and the calculation of the total power lost to the wall, (2) the scaling of this power with input power for a wide range of input powers and plasma parameters, (3) the variation of the wall power flux with gas puffing, and (4) the detailed correlation of the power signal 
with other impurity and instability signals for internally disruptive and grossly disruptive discharges.

\section{THE MEASUREMENT AND ITS INTERPRETATION}

The Oak Ridge Tokamak (ORMAK) [13] and some of the main studies conducted with it $[1,14]$ have been described elsewhere. For this discussion, the pertinent ORMAK parameters are major radius $\mathrm{R}=80 \mathrm{~cm}$, minor (1imiter) radius $a_{\ell}=23 \mathrm{~cm}$, liner (wal1) radius $a_{w}=25.5 \mathrm{~cm}$, toroidal field $B_{t}=10-26 \mathrm{kG}$, plasma current $I=60-175 \mathrm{kA}$, central chord-averaged electron density $\vec{n}_{e}=1-6 \times 10^{13} \mathrm{~cm}^{-3}$, and input power $P=100-1000 \mathrm{~kW}$. The experiments to be discussed were conducted with ohmically heated hydrogen plasmas supplemented in some cases with up to $350 \mathrm{~kW}$ of $\mathrm{H}^{0}$ beam injection.

The measurement of the wall power is based on a thin $(40-\mu \mathrm{m})$, 3-mm-diam, $\mathrm{LiTaO}_{3}$ pyroelectric element [15], the output current of which is proportional to the instantaneous incident power because the pyroelectric (polarization) current generated is proportional to the time rate of change of the temperature of the sensitive element. The constant of proportionality is essentially independent of detector temperature rise $\left(<0.15 \% /{ }^{\circ} \mathrm{C}\right)$. The inherently fast time response of the detector is limited to $>100 \mu$ s by the current amplifier used rather than by the thermal time constants ( $400 \mathrm{~ms}$ ) associated with the pyroelectric element. 
Power detection efficiency of the detector is approximately unity both for particles and for radiation from the visible $\left(\imath^{5000-} \AA\right)$ into the $x$-ray $(\sim 1-\AA)$ region; the detector reflectivity is negligible over the photon energy range for which significant transport of energy to the wall is expected in ORMAK. Absolute power calibration of the detector with $10-$ to $20-\mathrm{keV} \mathrm{H}^{0}$ beams and a HeNe laser (6328 $\AA$ ) gives the same value as the manufacturer's calibration [15] to within $<^{<5 \%}$. In addition, the detector does not respond to a relatively high current ( $\sim 1 \mu \mathrm{A})$ but low voltage (a few volts) electron beam with little relative power (much less than the $20-\mathrm{mW} / \mathrm{cm}^{2}$ detection threshold). By comparison, the threshold for polarization currents detected is $\prec_{10}^{-9} \mathrm{~A}$, so the detector responds only to incident power and not to current. Also, if the 100-us time response of the $10^{-7} \mathrm{~A} / \mathrm{V}$ current amplifier is sacrificed, an improvement of up to two orders of magnitude in detection sensitivity can be obtained by using higher gain current amplifiers.

The detector does not distingulsh between partlcle and radiated power fluxes. However, for the plasma parameters studied (except for the injection cases discussed later), the power input to the ions was much less than the ohmic power input, $P_{\text {OHI }}$, varying from $25 \%$ to $20 \%$ of $\mathbf{P}_{\mathrm{OH}}$, so that the wall power signal represents the electron power losses. This fact plus direct measurements and model calculations of the chargeexchange flux indicate that charge-exchange losses are but a small part of the detected signal. In addition, the detected signal remains constant as the detector is moved $2 \mathrm{~cm}$ radially outward from the liner 
wall $\left(r>a_{w}\right)$, indicating that the detected power is not carried by charged particles. This is as expected, since the toroidal field in the shadow of the limiter should prevent these particles from reaching the walls and thus the detector. Therefore, we conclude that the detected power is mainly due to impurity radiation in the plasma volume.

The detector response to a typical ORMAK discharge is shown in Fig. 1 along with the behavior of the main plasma parameters. For this discharge $I=120 \mathrm{kA}, B_{T}=18 \mathrm{kG}\left[\right.$ [1imiter safety factor $q\left(a_{\ell}\right)=5$ ], and $\bar{n}_{e}=2.3 \times 10^{13} \mathrm{~cm}^{-3}$. Except for the time correlation studies discussed later, only the quasi-steady-state behavior (typically at $245 \mathrm{~ms}$ ) is considered here.

Estimates of the spatial distribution of the plasma radiation are obtained by varying the distance from the detector to the liner, $x$, from one discharge to another, thereby changing the plasma volume seen by the detector through a fixed liner aperture. This arrangement is illustrated in Fig. 2 along with two extreme representations of the emitting volume: a small central core (I) and a thin surface layer (II). In order to unfold the detector signal vs probe distance data, $P_{\text {det }}(x)$, we assume various models for the radial distribution of the emitting plasma and choose that distribution which gives a calculated $\mathrm{P}_{\operatorname{det}}(\mathrm{x})$ closest to that measured. For all dislitibutiono, the signal is approximately constant for small detector-to-liner distances, where the probe aperture rather than the liner aperture determines the detector's acceptance angle (out to detector position 2 in Fig. 2). This approximate constancy 
arises because for a given distance $s=a_{w}-r+x$ from the detector to an emitting element at radius $r$, the emitting volume seen by the detector varies as $s^{2}$ but the fraction of that radiation detected varies as $1 / \mathrm{s}^{2}$. At larger $x(>2 \mathrm{~cm}$ or beyond position 2 in Fig. 2), the falloff of $P_{\text {det }}(x)$ depends on the fraction of the radiating volume within the acceptance angle formed hy the detector and the liner aperture.

Figure 3 shows some typical $\mathrm{P}_{\text {det }}(\mathrm{x})$ data obtained for the plasma conditions shown in Fig. 1 at $t=45 \mathrm{~ms}$. Also shown are three curves with values calculated based on the assumption of a uniform power density in an emitting shell characterized by a mean radius $r_{m}$ and thickness $\Delta r$. The calculated curves have been normalized to give the minimum rms percentage error, $\varepsilon_{\text {rms }}$, between the data and the calculated $\mathrm{P}_{\operatorname{det}}(\mathrm{x})$; the normalization constant along with the detector power calibration and viewing geometry then give the absolute power flux. The three curves in Fig. 3 show a "best fit" to the data (curve $2, \mathrm{r}_{\mathrm{m}}=7 \mathrm{~cm}, \Lambda \underline{H}=12 \mathrm{~cm}$, $\varepsilon_{\text {rms }}=8 \%$ ) and two "poor fits," a small central core extending over the central quarter of the plasma (curve $1, \varepsilon_{\text {rms }}=18 \%$ ) and a shell extending over the outer half of the plasma radius (curve 3, rms $\equiv 31 \%$ ).

The relative uncertainty in the fitting proccdure can be seen from Fig. 4, which is a plot of the rms percentage error for differenl allowahle comblnations of $r_{m}$ and $\Delta r$. Results obtained through this procedure indicate that the most probable mean position $r_{m}$ of the radiating volume is centered at 7-9 cm, not only for the 120-kA discharge of Fig. 1 but also over a wide range of plasma parameters. These comparisons are 
sensitive to the mean position $r_{m}$ of the emitting volume, but not to its thickness $\Delta r$ (as demonstrated in Fig. 4) and hence not to the exact form of the radial distribution. More refined estimates of the radial distribution could not be made on ORMAK but will be carried out on the Impurity Study Experiment (ISX) [16] with an array of highly collimated pyroelectric detectors.

The actual $\mathrm{P}_{\mathrm{det}}(\mathrm{x})$ calculation takes into account the extent of the plasma in the toroldal direction (perpendicular to the plane of Fig. 2) and the angle of incidence of the power flux at the detector. The radiating volume is taken to be cylindrical rather than toroidal, thus overestimating the wall power by $\leqslant 10 \%$ for reasonable source distributions. A single detector was used, located on the outside of the torus $90^{\circ}$ from the limiter, and the wall power flux was assumed to be uniform over the liner area. Support for this last assumption is derived from previous measurements [17] which used a toroidal array of liner thermocouples and indicated a variation of less than $10 \%$ in wall power around the torus. Although information is lacking on the poloidal wall power distribution, this too was assumed to be uniform. Finally, wall reflection of the radiation was neglected because this should be unimportant [18] for the energy range $(\lambda \sim 10-200 \AA)$ for which significant wall energy flux is expected in ORMAK.

Although it is possible to obtain information on the mean radius of the radiating distribution from the procedure just discussed and illustrated in Figs 3 and 4, little use is made of this capability. Instead, 
the discussion focuses on the varlation of the total wall power with input power and with its time dependence (on different time scales) correlated with other plasma parameters.

\section{STEADY-STATE WALL POWER SCALING}

'l'he relation between the wall power losses and the ohmic power input was determined for a wide range of power inputs and plasma parameters. In this study, the parameters $I, B_{T}$, and $\bar{n}_{e}$ were each varied about the base parameter set [19]. The individual ranges covered were as follows: the "I scan" was from 62 to $175 \mathrm{kA}\left[\mathrm{q}\left(\mathrm{a}_{\ell}\right)\right.$ varied from 11.6 to 4.1 , with $\mathrm{B}_{\mathrm{T}}=21.5 \mathrm{kG}$, the "B $\mathrm{B}_{\mathrm{T}}$ scan" was from 15.6 to $24.1 \mathrm{kG}$ [ $q\left(a_{\ell}\right)$ varied from 4.2 to 6.6 , with $I=120 \mathrm{kA}$ ], and the " $\bar{n}_{e}$ scan" was from 1.2 to $2.7 \times 10^{13} \mathrm{~cm}^{-3}\left[\mathrm{q}\left(\mathrm{a}_{\ell}\right)=5\right]$. In another sequence ("constant $\left.q^{\prime \prime}\right)$, the initial hydrogen filling pressure $\left(5 \times 10^{-4}\right.$ torr $)$ and $q\left(a_{\ell}\right)=5$ were held constant as the plasma current was varied from $68 \mathrm{kA}$ to $175 \mathrm{kA}\left(\mathrm{B}_{\mathrm{T}}=9.5 \mathrm{kG}\right.$ to $\left.26 \mathrm{kG}\right)$, producing a density $\left(\overline{\mathrm{n}}_{\mathrm{e}}\right)$ variation from $9 \times 10^{12} \mathrm{~cm}^{-3}$ to $2.7 \times 10^{13} \mathrm{~cm}^{-3}$; a central electron temperature $\left[\mathrm{T}_{\mathrm{e}}(0)\right]$ variation from $600 \mathrm{eV}$ to $1500 \mathrm{eV}$; and an input power $\left(P_{\mathrm{OH}}\right)$ variation from $200 \mathrm{~kW}$ to $500 \mathrm{~kW}$.

Wall power data for these sequences and data for some gas puffing experiments (discussed in detail in Section 4) are shown in Fig. 5. For all cases, there is an approximately linear relation between $P_{\text {wall }}$ and $\mathrm{P}_{\mathrm{OH}}$, with only slight systematic trends in the ratio $\mathrm{P}_{\text {wall }} / \mathrm{P}_{\mathrm{OH}}$ for the 
different parameter scans. For example, $\mathrm{P}_{\text {wall }} / \mathrm{P}_{\text {OH }}$ increases from $52 \%$ to $60 \%$ as I Increases from $68 \mathrm{kA}$ to $175 \mathrm{kA}$ in the constant $\mathrm{q}$ sequence but decreases from $70 \%$ to $62 \%$ as I increases from $80 \mathrm{kA}$ to $174 \mathrm{kA}$ in the I scan series of experiments. Also, there is a general increase in $\mathrm{P}_{\text {wall }} / \mathrm{P}_{\mathrm{OH}}$ (from $58 \%$ to $75 \%$ ) as $\mathrm{q}\left(\mathrm{a}_{\ell}\right)$ is varied from 4.1 to 11.6 for both the $I$ scan and the $B_{T}$ scan data. Despite these small but apparently systematic differences, the main conclusion from these studies is that a large, relatively constant fraction $\left(\mathrm{P}_{\text {wall }} / \mathrm{P}_{\mathrm{OH}} \approx 60 \%\right)$ of the input ohmic power is lost to the wall as radiation over a wide range of input powers and plasma parameters.

This conclusion still holds when a substantial part of the electron power input comes from neutral beam injection. The addition of up to $350 \mathrm{~kW}$ of $\mathrm{H}^{0}$ beam injection extends the total power input in this scaling study to $1 \mathrm{MW}$. There is a clear distinction between the fraction of the total input power lost to the wall in discharges preceded by oxygen discharge cleaning (the usual condition in this study) and the fraction lost in those preceded by hydrogen discharge cleaning. In the first case [1], the ohmic power input dominates the injection power input and the ion power input is a small fraction of the total power input. Under these circumstances, the same fraction ( $\sim 60 \%)$ of the power is lost to the walls as in the ohmic heating study (also with oxygen discharge cleaning) shown in Fig. 5.

However, in the second case (i.e., hydrogen discharge cleaning and higher injection power), the ion power input is usually not a small 
fraction of the total power, and typically only $40 \%$ of the total power input is detected as wall power. When the wall power is compared with the electron power input, however, the same fraction (i.e., $260 \%$ ) is still obtained. Because the impurity radiation with high power neutral beam infection ( $\mathrm{P}_{\text {inj }} \approx 3 \times \mathrm{P}_{\mathrm{OH}}$ ) increases only in proportion to the added electron power input ( $0.5 \mathrm{P}_{\text {inj }}$ ), we conclude that there is no evidence for disproportionate impurity influx or losses specific to injection. Also, the detector signal remains a measure of mainly rad1ative power flux, even with neutral beam injection.

Thus, approximately the same fraction of the electron power input is lost to the wall independent of the plasma parameters and the power input over the wide range studied. In addition, apparently a much smaller fraction of the ion input power is detected on the walls. Measurements of the absolute charge-exchange flux also indicate that only a small fraction of the ion power input is lost to the walls via charge exchange, even with large ion power inputs from intensive neutral beam injection.

The approximately constant proportionality between total electron input power and $\mathrm{P}_{\text {wall }}$ for varying power input is also observed in the course of a discharge evolution, as shown in Fig. 6 . In this case, $340 \mathrm{~kW}$ of $\mathrm{H}^{0}$ beam injection (of which roughly half goes to the electrons) was added to $\sim 100 \mathrm{~kW}$ of ohmic heating power, causing an increase in electron power input and electron heating [20] and in the impurity 
radiation losses to the wa11. There is also a corresponding increase in the impurity radiation seen spectroscopically, also shown in Fig. 6 . These signals are representative of the behavior of $0^{6+}(21.6 \AA)$ and a segment of continuum thought to be closely spaced lines of tungsten $(20.1 \AA)$.

The estimates of $260 \%$ of the total input power going to the wa11 are supported by calorimetric measurements made with a radially movable point limiter [21, 17] and with an array of wall thermocouples [17]. These measurements showed only $5-6 \%$ of the ohmic heating power on the point limiter when it was inserted $7 \mathrm{~cm}$ inside the fixed limiter position for discharges with $I=80-95 \mathrm{kA}$ and $B_{T}=17 \mathrm{kG}$. In addition, in a different set of experiments (with $I=100-130 \mathrm{kA}, \mathrm{B}_{\mathrm{T}}=15 \mathrm{kG}$ ), the array of thermocouples showed $\sim 70 \%$ of the input power going to the walls. This conclusion, that most of the power goes to the walls and not to the limiter, is similar to that found on the TFR [2] and more recently on PLT [4], T-10 [20], and DITE [3] but is in distinct contrast to the observations on smaller devices such as T-3 [7]; ST [23], and ATC [8], which suggest that a larger fraction of the input is lost to the limiter. On the other hand, indications [17] are that $\mathrm{P}_{\text {wall }} / \mathrm{P}_{\text {INPUT }}$ increases systematically with increasing minor radius up to a plateau which includes valuee of $\mathrm{P}_{\text {wa1l }} / \mathrm{P}$ INPUT of $65-90 \%$ for PLT 141 . 


\section{VARIATION OF WALL POWER WITH GAS PUFFING}

The use of additional hydrogen gas puffing to increase the plasma density in ORMAK leads to discharge time behavior which depends on the density range achieved. For lower density $\left[\overline{\mathrm{n}}_{\mathrm{e}}\right.$ (peak) $\left.<4 \times 10^{13} \mathrm{~cm}^{-3}\right]$ discharges obtained with gas puffing, the detector signal closely follows the plasma density, as shown in Fig. 7 for $t>10 \mathrm{~ms}$ into the discharge. In this lase, the plasma current and voltage (and hence the ohmis powcr input) are approximately constant, as is the electrun temperarnre. This direct proportionality of the radiation signal to the plasma density may indicate a relatively constant impurity density. For higher plasma densities $\left(\bar{n}_{e} \gtrsim 4 \times 10^{13} \mathrm{~cm}^{-3}\right)$ obtained at higher current (I $\left.\sim 175 \mathrm{kA}\right)$, the wall power signal is nearly constant in time as the plasma density more than doubles. The power loss per plasma particle decreases as the density increases, although the electron temperature again remains relatively unchanged. This may indicate a reduction in the impurity density at the higher plasma density.

Still higher density is obtained with gas puffing at $175 \mathrm{kA}$ of plásma current by the addition of neutral beam injertion, as shuwn in Fig. 8. In this case, the impur1ty radiation loss actually decreases, along with the total input power to the electrons, as the density increases. Again, there is a rough proportionality between the wall power losses and the total electron power input. Here the electron temperature increases as a result of injection heating, however, and any interpretation in terms of impurity density is even more suspect than 
the rough indications discussed above. However, supporting these interpretations is the vacuum ultraviolet (VUV) spectroscopic observation that the intensity at $50 \AA$ falls even more rapidly as the density rises. For these discharges, most of the impurity radiation seen spectroscopically is in narrow band continua in the range of 20-70 $\AA$ from tungsten radiation [24]. Also, another indicator of light impurity (oxygen) density, $z_{\text {eff }}$, falls as the density rises, perhaps indicating a dilution effect.

5. TIME BEHAVIOR OF THE WALL POWER FLUX FOR UNSTABLE DISCHARGES

In addition to the gross power measurements for quasi-steady-state or slowly varying conditions (as discussed in the preceding sections), the detector also gives detailed information on the plasma behavior in unstable discharges, since instantaneous rather than time-integrated power is measured. Two examples are discussed in terms of the correlation of the wall power flux with other instability signals: (1) multiple minor disruptions and (2) large internal disruptions ("sawtooth oscillations").

Figures 9-11 show an example of an unstable discharge exhibiting repeated gross disruptions. The behavior of the macroscopic plasma parameters (wall power, electron density, discharge loop voltage, and plasma current) is shown in Fig. 9, and the instability (envelope of the $\mathrm{m}=2, \dot{\mathrm{B}}_{\theta}$ oscillations) and spectroscopic signals (CIII, $4650 \AA$; OVI, $1032 \AA$; and $H_{\beta}, 4860 \AA$ ) are shown in Fig. 10. The large initial peak in 
the detector signal is correlated with $\mathrm{H}_{B}$ and impurity light intensities and with the $\dot{\mathrm{B}}_{\theta}$ signal. This peak reflects factors such as the initial ionization and plasma-wall interaction, and it falls as the discharge column position becomes well stabilized and confinement improves. Each plasma interaction with the wall brings in additional impurities, as evidenced by the spikes in the CIII and OVI light intensities. The relative time sequence of these signals is better illustrated on the expanded time scale shown in Fig. 11.

In general, the physical processes leading to a disruptive instability are varied and complex, and no one discharge, including that of Figs. 9-11, should be taken as a typical example of the phenomenon. For this particular discharge, as shown in Fig. 10, the first evidence of a disturbance is a rise in the amplitude of the $m=2 \dot{B}_{\theta}$ oscillations beginning at $\sim 37 \mathrm{~ms}$ into the discharge. From the expanded time scale of Hig. 11, we see that at the onset of the disruption there is an outward plasma shifr, à decrease in electron density and loop voltage, and increases in wall power flux and CIII, $\mathrm{H}_{\beta}$, and OVI line intensities, all of which occur essentially simultaneously. Peak.s of the plasma shift, the wall power signal, the oVI intensity, and the $\dot{\mathrm{B}}_{\theta}$ envelope all occur $20.5 \mathrm{~ms}$ later than the peaks of the ${ }_{\beta}$ and CIII lineo and the minimum $\bar{\pi}_{\mathrm{e}}$ and loop voltage. Apparently the disruption arising from the $\mathrm{m}=2$ instability drives plasma to the wall, producing an increase in the neutral gas $\left(\mathrm{H}_{\beta}\right)$ and impurity (CIII and OVI) influxes. The OVI peak (ionization potential of $\sim 138 \mathrm{eV}$ ) occurs at a higher electron temperature 
(assumed to be $\sim 40 \mathrm{eV}$ [6] or a few centimeters inside the limiter radius), and its $\sim 0.5 \mathrm{~ms}$ time delay is not understood, but could be due to a number of reasons, including an Inward flow of oxygen or changes in electron temperature and density profiles. During these relatively small disruptions, power flow to the liner sharply increases as the plasma moves outward. The area under each peak in Fig. Il indicates an additional energy loss of $\sim 250 \mathrm{~J}$ as a result of each disturbance. The plasma density and wall power then recover on a time scale of $28 \mathrm{~ms}$. In addition to large macroscopic plasma disturbances, tokamak plasmas can undergo large amplitude internal disruptions while exhibiting only small amplitude MHD $\dot{B}_{\theta}$ oscillations on external magnetic loop probes. Corresponding fluctuations are found to be superimposed on signals from the pyroelectric wall power monitor. Figure 12 shows the detector signal for a discharge which exhibited large amplitude soft $x$-ray "sawtooth" oscillations $[25,26]$. The period of these relaxation oscillations is the same as that seen on soft $x$-ray emissions and has the fast increase characteristic of energy flow outside the $q=1$ surface, rather than that of the plasma core. The amplitude of the sawtooth riding on the detector trace is $\sim 6 \%$ of the total signal. This supports measurements with the PIN diode array which indicate that these oscillations are not the dominant factor in the total power flow in ORMAK [1]. 


\section{CONCLUSIONS}

A pyroelectric detector has been used to make time-resolved measurements of plasma power losses to the walls in ORMAK. A large and relatively constant fraction ( $60 \%$ ) of the electron power is lost to the liner wall as impurity radiation over a wide range of plasma parameters, both with ohmic heating alone and with neutral beam injection. There appears to be no increase in the fraction of power lost to the wall when injection is added, and at higher densities obtained with injection plus gas puffing, the radiative loss actually decreases as density increases. Detailed time studies, made possible by the fast response of the pyroelectric detector, show fluctuations in wall power losses to be well correlated with those in VUV impurity radiation and various plasma parameters. This is especially apparent in neutral beam injection and gas puffing experiments and for discharges which suffer gross disruptions. Finally, internal disruptions and charge-exchange losses do not play a major role in the direct transport of energy from the plasma to the wall in ORMAK.

\section{ACKNOWLEDIMENTS}

The authors gratefully acknowledge contributions to this work from several members of the ORMAK group and in particular specific contributions by and discussions with M. Murakami and R.-C. Isler, contributions 
by S. M. DeCamp and P. H. Edmonds, and encouragement of this work by I. A. Berry and J. F. Clarke.

This research was sponsored by the Department of Energy under contract with Union Carbide Corporation. 


\section{REFERENCES}

[1] BERRY, L. A., BUSH, C. E., CALLEN, J. D., COLCHIN, R. J., DUNLAP, J. L., EDMONDS, P. H., ENGLAND, A. C., FOSTER, C. A., HARRIS, J. H., HOWE, H. C., ISLER, R. C., JAHNS, G. L., KETTERER, H. E., KING, P. W., LYON, J. F., MIHALCZO, J. T., MURAKAMI, M., NEIDIGH, R. V., NEILSON, G. H., PARÉ, V. K., SHAEFFER, D. L., SWAIN, D. W., WILGEN, J. B., WING, W. R., ZWEBEN, S. J., in Plasma Physics and Controlled Nuclear Fusion Research (Proc. 6th Int. Conf. Berchtesgaden, 1976), 1, IAEA, Vienna (1977) 49 .

[2] EQUIPE TFR, in Plasma Physirs and Controlled Nuclear Fusion Research (Proc. 6th Int. Conf. Berchtesgaden, 1976), 1, IAEA, Vienna (1977) 35.

[3] PAUL, J. W. M., AXON, K. B., BURT, J., CRAIG, A. D., ERENTS, S. K., FIELDING, S. J., GOODALL, D. H. J., GTLL, R. D., HEMSWORTH, R. S., HOBBY, M., HUGILL, J., MCCRACKEN, G. M., POSPIESZCZYK, A., POWELL, B. A., PRENTTLLE, R., REID, G. W., SUMMERS, D. D. R., WILSON, C. M., in Plasma Physics and Controlled Nuclear Fusion Research (Proc. 6 th Int. Conf. Berchtesgaden, 1976), 2, IAE $\Lambda$, Vienua (1977) 269.

[4] HSUAN, H., private communlatation (1977); SCHIVELL, J. F., HSUAN, H., Bu11. Am. Phys. Soc. 21 (1976) 1159.

[5] DIMOCK, D., ECKHARTT, D., EUBANK, H., HINNOV, E, , JOHNSON, L. C., MESERVEY, E., TOLNAS, E., GROVE, D. J., in Plasma Physics and Controlled Nuclear Fusion Research (Proc. 4th Int. Conf. Madison, 1971), 1, IAEA, Vienna (1971) 451. 
[6] Fusion Energy Division Annual Progress Report for Period Ending December 31, 1976, ORNL-5275, Oak Ridge (1977) 46.

[7] GORELIK, L. L., MIRNOV, S. V., NIKOLAEVSKY, V. G., SINITSYN, V. V., Nuc1. Fusion $\underline{12}$ (1972) 185.

[8] HSUAN, H., BOL, K., ELLIS, R. A., Nucl. Fusion 15 (1975) 657.

[9] HUGILL, J., FIELDING, S. J., GILL, R. D., HOBBY, M., McCRACKEN, G. M., PAUL, J. W. M., PEACOCK, N. J., POWELL, B. A., PRENTICE, R., STOTT, P. E., in Controlled Fusion and Plasma Physics (Proc. 8th Europ. Conf. Prague, 1977), proceedings to be published.

[10] T.F.R. Group (presented by J. P. Girard), in Controlled Fusion and Plasma Physics (Proc. 8th Europ. Conf. Prague, 1977), proceedings to be published.

[11] BUSH, C. E., EDMONDS, P. H., ENGLAND, A. C., LYON, J. F., Bull. Am. Phys. Soc. 20 (1975) 1299.

[12] YAMAMOTO, S., MAEDA, H., SHIMOMURA, Y., ODAJIMA, K., NAGAMI, M., KIMURA, H., SENGOKU, S., OHTSUKA, H., UEDA, N., FUNAHASHI, A., MATOBA, T., TAKEUCHI, H., TAKAHASHI, K., KASAI, S., SUGIE, T., SHIHo, M., KaWAKAMI, T., KUMAGAI, K., YAMAUCHI, T., SHOJI, T., TOKUTAKE, T., ANNO, K., ARAI, T., SHIBATA, T., HIRATSUKA, H. , TANAKA, M., TANAKA, Y., KUNIEDA, S., in Controlled Fusion and Plasma Physics (Proc. 8th Europ. Conf. Prague, 1977), proceedings to be published. 
[13] BARNETT, C. F., CLARKE, J. F., DAVIS, R. C., DORY, R. A., EDMONDS, P. H., FORSEN, H. K., HOGAN, J. T., KELLEY, G. G., LUBIN, M. J., McNALLY, J. R., MORGAN, O. B., MURAKAMI, M., ROBERTS; M., SOURES, J. M., STEWART, L. D., STIRLING, W. L., WIDNER, M. M., in Plasma Physics and Controlled Nuclear Fusion Research (Proc. 4th Int. Conf. Mndioon, 1971) 1 , JAFA, Vienna (1971) 347.

[14] BERRY, L. A., CALLEN, J. D., CLAKKH, J. F., COLCHIN, R. J., CIUUME, E. C., DUNLAP, J. L., EDMONDS, P. H., HASTE, G. R., HOGAN, J. T., ISLER, R. C., JAHNS, G. L., LAZAR, N. H., LYON, J. F., MURAKAMI, M., NEIDIGH, R. V., WING, W. R., in Plasma Physics and Controlled Nuclear Fusion Research (Proc."5th Int. Conf. Tokyo, 1974), $\underline{1}$, IAEA, Vienna (1975) 101; ORMAK GROUP (presented by LYON, J. F.), in Controlled Fusion and Plasma Physics (Proc. 7th Europ. Conf. Lausanne, 1975) 2 , 24.

[15] Pyroelectric detectors supplied by the Laser Precision Corporation, Utica, New York, U.S.A.

[16] COLCHIN, R. J., JERNIGAN, T. C., J. Nuc1. Mater. 63 (1976) 83.

117] EDMONDS, P. H., ENGLAND, A. C., submitted to Nuc1. Fusion (1977).

[18] SAMSON, J. A. R., Techniques of Vacuum U1traviolet Spectroscopy, John Wiley and Sons, Inc., New York (1967) Chapter 2.

[19] Thermonuclear Vivision Ánnual Progress lleport for Puliod Inding December 31, 1975, ORNL-5154, Oak Ridge (1976) 13. 
[20] MURAKAMI, M., ISLER, R. C., LYON, J. F., BUSH, C. E., BERRY, L. A., DUNLAP, J. L., DYER, G. R., EDMONDS, P. H., KING, P. W., McNEILL, D. H., Phys. Rev. Lett. 39 (1977) 615.

[21] KELLEY, G. G., BARNETT, C. F., BERRY, L. A., BUSH, C. E., CALLEN, J. D., CLARKE, J. F., COLCHIN, R. J., DORY, R. A., ENGLAND, A. C., HOGAN, J. T., McNALLY, J. R., MURAKAMI, M., NEIDIGH, R. V., ROBERTS, M., ROME, J. A., WING, W. R., Toroidal Plasma Confinement (Proc. 3rd Int. Symp. Garching, 1973) B3-1.

[22] BERLIZOV, A. B., BOBROVSKIJ, G. A., BAGDASAROV, A. A., VASIN, N. L., VERTIPOROKH, A. N., VINOGRADOV, V. P., VINOGRADOVA, N. D., GEGECHKORY, N. M., GORBUNOV, E. P., DNESTROVSKIJ, Yu. N., ZAVERYAEV, V. S., IZVOZCHIKOV, A. B., LUK'YAKNOV, S. Yu., LYSENKO, S. E., MAKSIMOV, Yu. S., NOTKIN, G. E., PETROV, M. P., POPKOV, G. N., RAZUMOVA, K. A., STRELKOV, V. S., SHCHEGLOV, D. A., in Plasma Physics and Controlled Nuclear Fusion Research (Proc. 6th Int. Conf. Berchtesgaden, 1976) 1, IAEA, Vienna (1977) 3.

[23] DIMOCK, D. L., EUBANK, H. P., HINNOV, E., JOHNSON, L. C., MESERVEY, E. B., Nuc1. Fusion 13 (1973) $2 \% 1$.

[24] ISLER, R. C., NEIDIGH, R. V., COWAN, R. D., Tungsten Radiation from Tokamak-Produced Plasmas, to be published.

[25] VON GOELER, S., STODIEK, W., SAUTHOFF, N., Phys. Rev. Lett. 33 (1974) 1201.

[26] Thermonuclear Division Annual Progress Report for Period Ending December 31, 1975, ORNL-5154, Oak Ridge (1976) 32. 
THIS PAGE

\section{WAS INTENTIONALLY LEFT BLANK}


FIGURE CAPTIONS

Fig. 1. Time history of the plasma parameters for a typical ORMAK discharge: plasma current (I), loop voltage (V), central chord-averaged electron density $\left(\bar{n}_{e}\right)$, and pyroelectric detector signal ( $P_{\text {wall }}$ ).

Fig. 2. The detector measurement geometry showing two extreme representations ( $I$ and $I I$ ) for the plasma radiation. As the detector moves radially from position 1 to position 3, the detected signal changes in response to the changing acceptance angle and the radial distribution of the source.

Fig. 3. Variation of signal with detector-to-liner distance for the plasma conditions shown in Fig. 1. The circles are data points at $45 \mathrm{~ms}$ for the 120-kA discharge. The curves 1,2 , and 3 are calculated for different assumed radial source distributions characterized by a mean radius $r_{m}$ and thickness $\Delta r$.

Fig. 4. Variation of the rms percentage error between the data of Fig. 3 and normalized curves calculated for a cylindrical radiating shell cliaracterized by mean radius $r_{m}$ and thickness $\Delta r$. The points 1 , 2 , and 3 correspond to curves 1, 2, and 3 in Fig. 3.

Fig. 5. Approximate linearity between the steady-state ( $t=45 \mathrm{~ms}$ ) wall power estimate and the ohmic power input for the different experiments described in the text. 
Fig. 6. The increase of wall power, total power input to electrons, and VUV spectroscopic signals as a result of neutral beam injection. Signals for impurity radiation at $21.6 \AA\left(0^{6+}+\right.$ continuum) and $20.1 \AA$ (continuum) are indicated.

Fig. 7. Correlation between the wall power signal and the lineaveraged electron density for hydrogen gas puffing in a low density $\left(\overline{\mathrm{n}}_{\mathrm{e}}=2.5 \times 10^{13} \mathrm{~cm}^{-3}\right)$, low current $(I=100 \mathrm{kA})$ hydrogen discharge.

Fig. 8. Reduction of radiative power loss as a resull ur hydrogen gas puffing (G.P.) with injection in a 175-kA hydrogen discharge.

Fig. 9. Correlation of wall power signal with other gross plasma parameters for a $120-\mathrm{kA}, 18-\mathrm{kG}, \overline{\mathrm{n}}_{\mathrm{e}} \approx 3 \times 10^{13} \mathrm{~cm}^{-3}$ discharge exhibiting repeated external disruptions.

Fig. 10. Relation between an MHD instabilfty signal (envelope of poloidal $\dot{\mathrm{B}}_{\theta}$ oscillations) and various spectroscopic signals related to impurities (CIII, OVI) and to neutral hydrngen for the diocharge shown in Fig. 9.

Fig. 11. Time relationship of wall power signal to the different gross plasma parameter signals and the impurity and instability relatcd signals shown in Figs 9 and 10 on an expanded time scale (44-68 ms).

Fig. 12. Response of the wall power signal to a regular, large amplitude, long period sawtooth oscillation (internal disruptions) in the plasma interior. The lower trace is an expansion ( $1 \mathrm{~ms} / \mathrm{division}$, $0.04 \mathrm{~V} /$ division) of the intensified portion of the upper trace (10 ms/division, $0.4 \mathrm{~V} /$ division). 


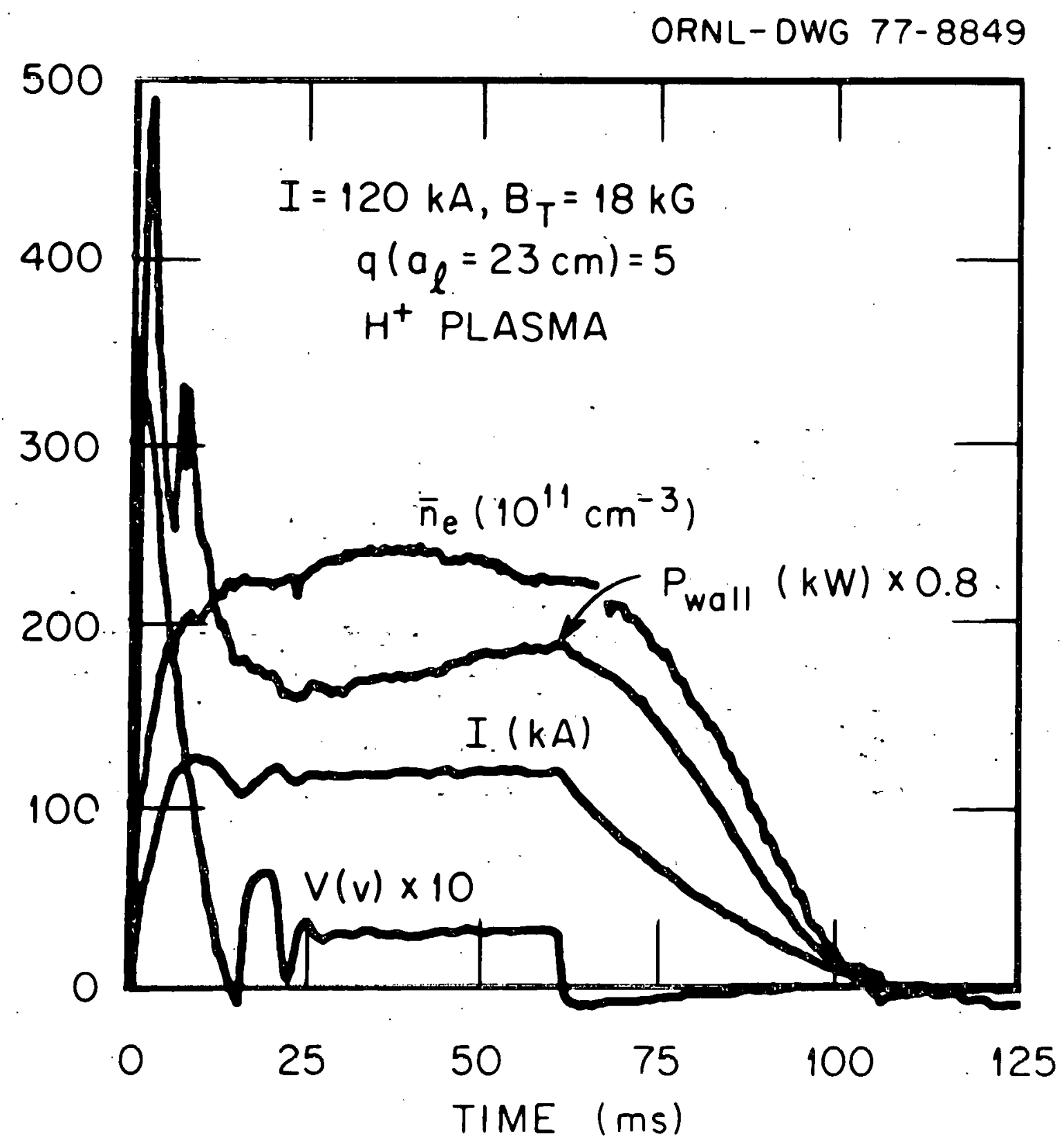

Fig. 1 
ORNL-DWG 76-4290R

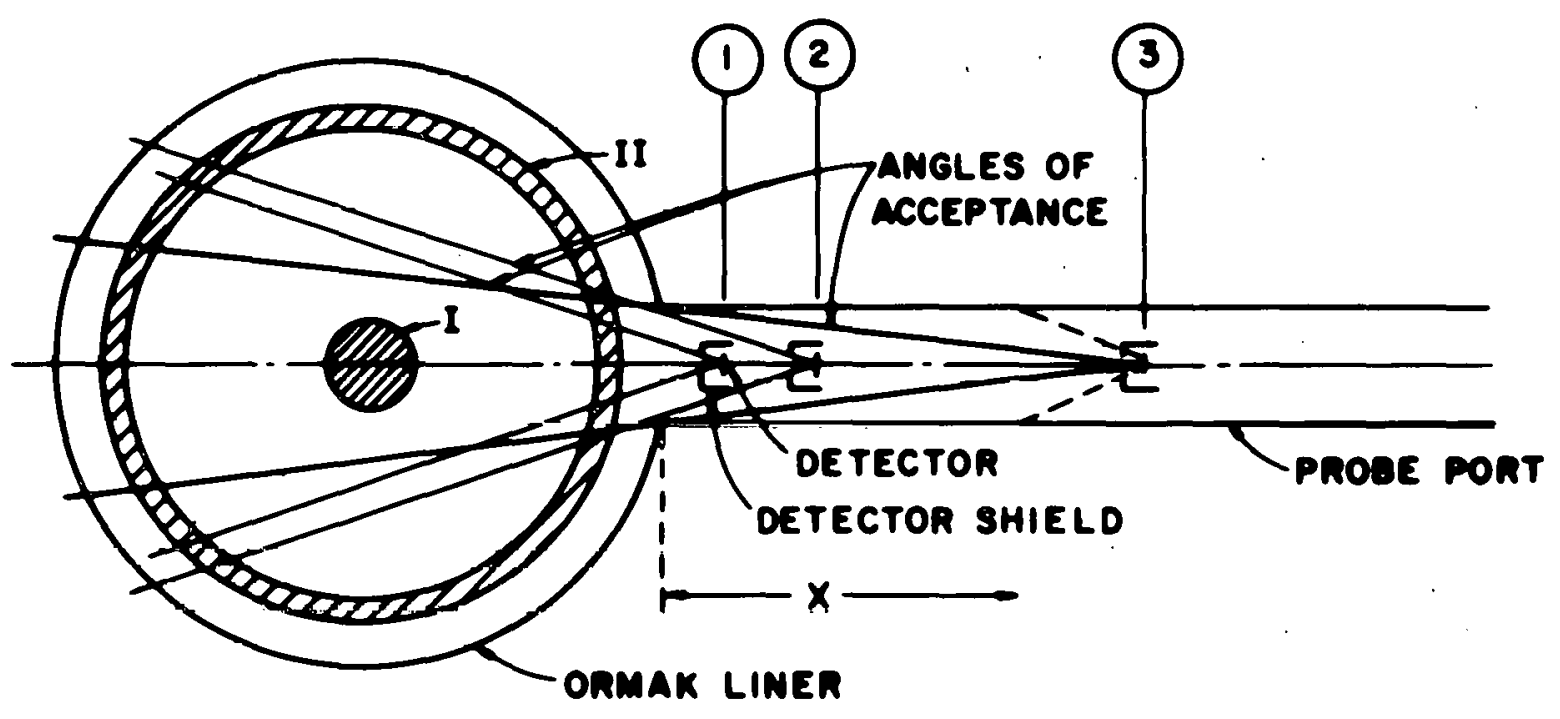

Fig. 2 


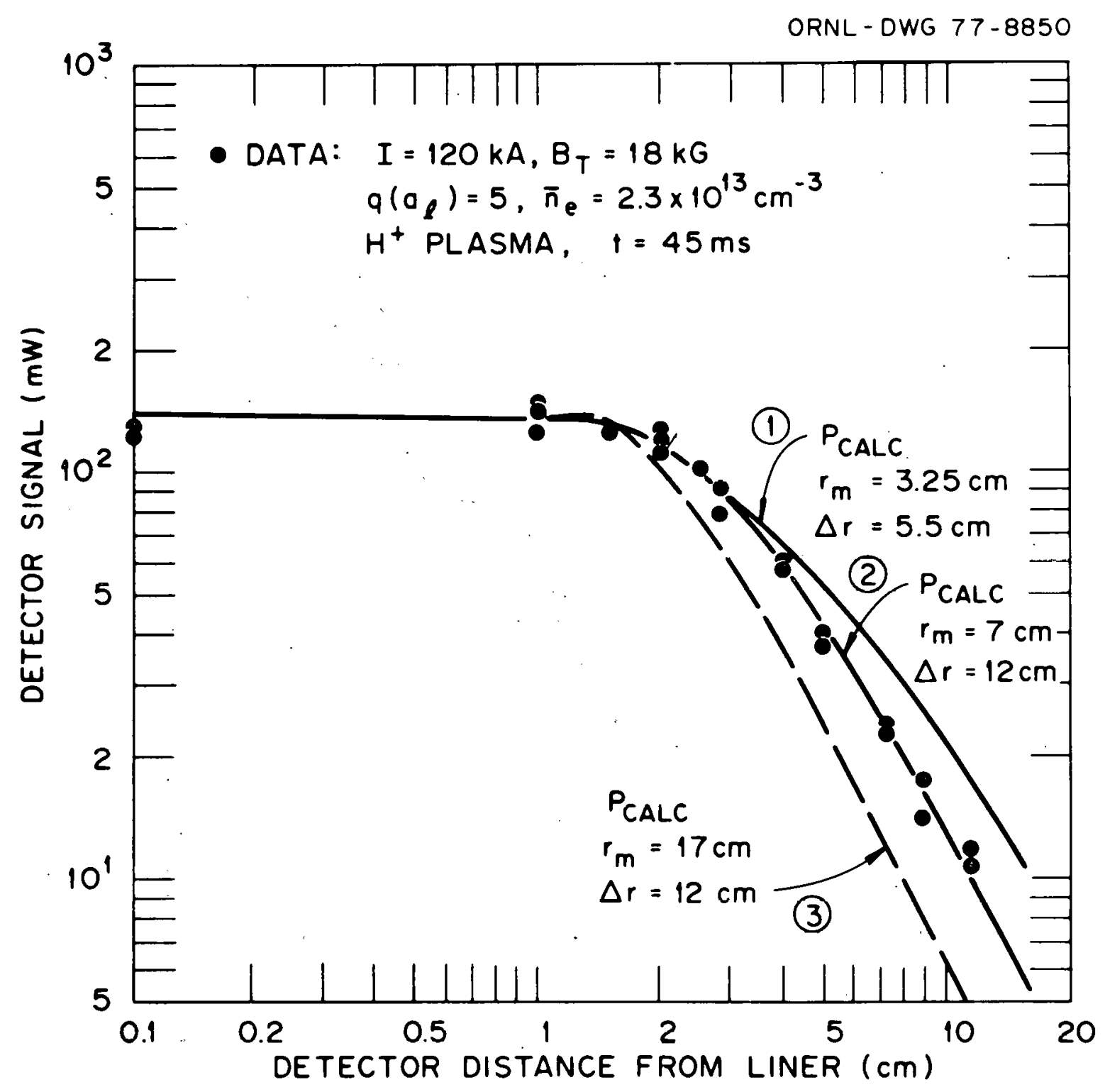

Fig. 3 


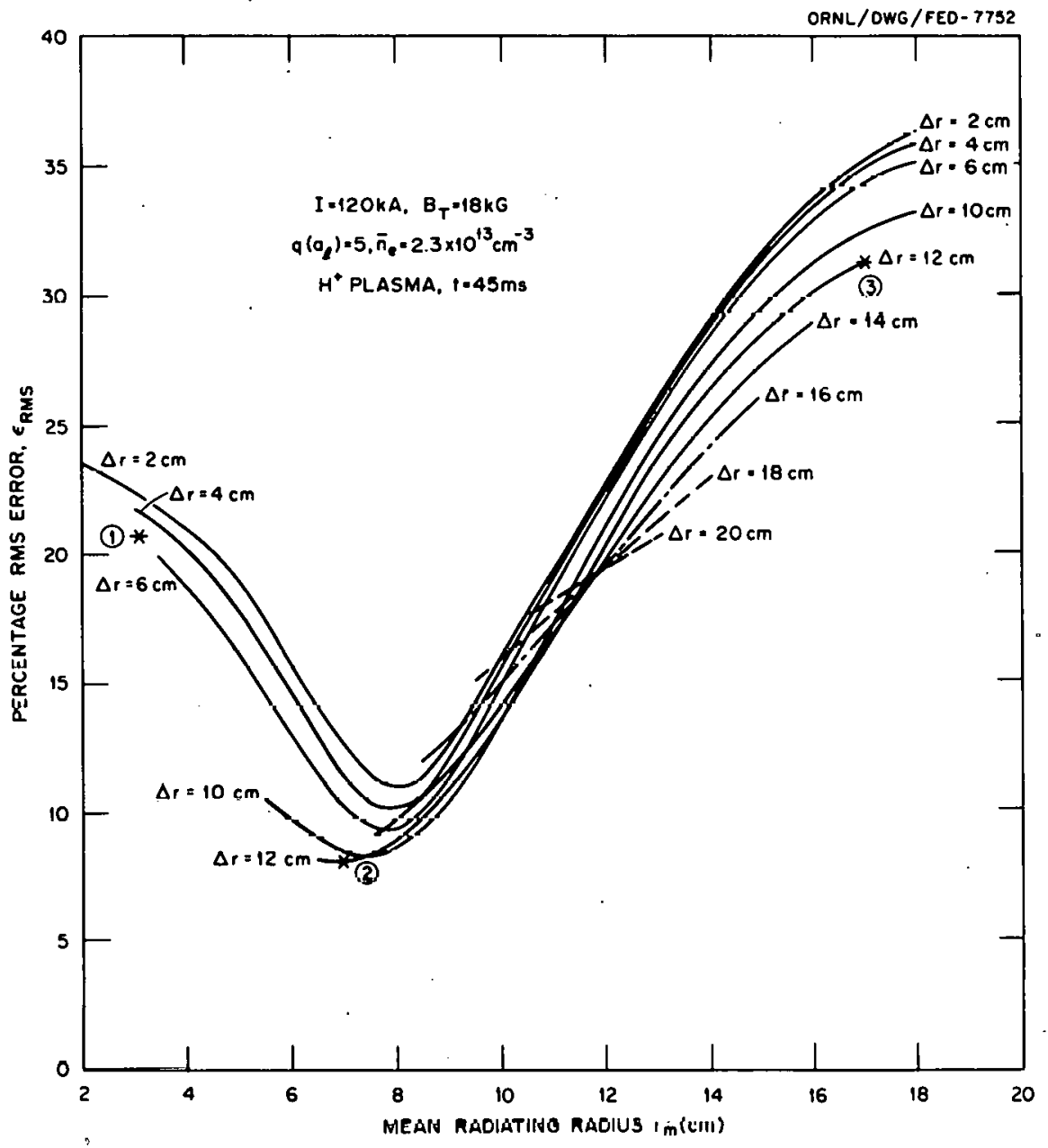

Fig. 4 


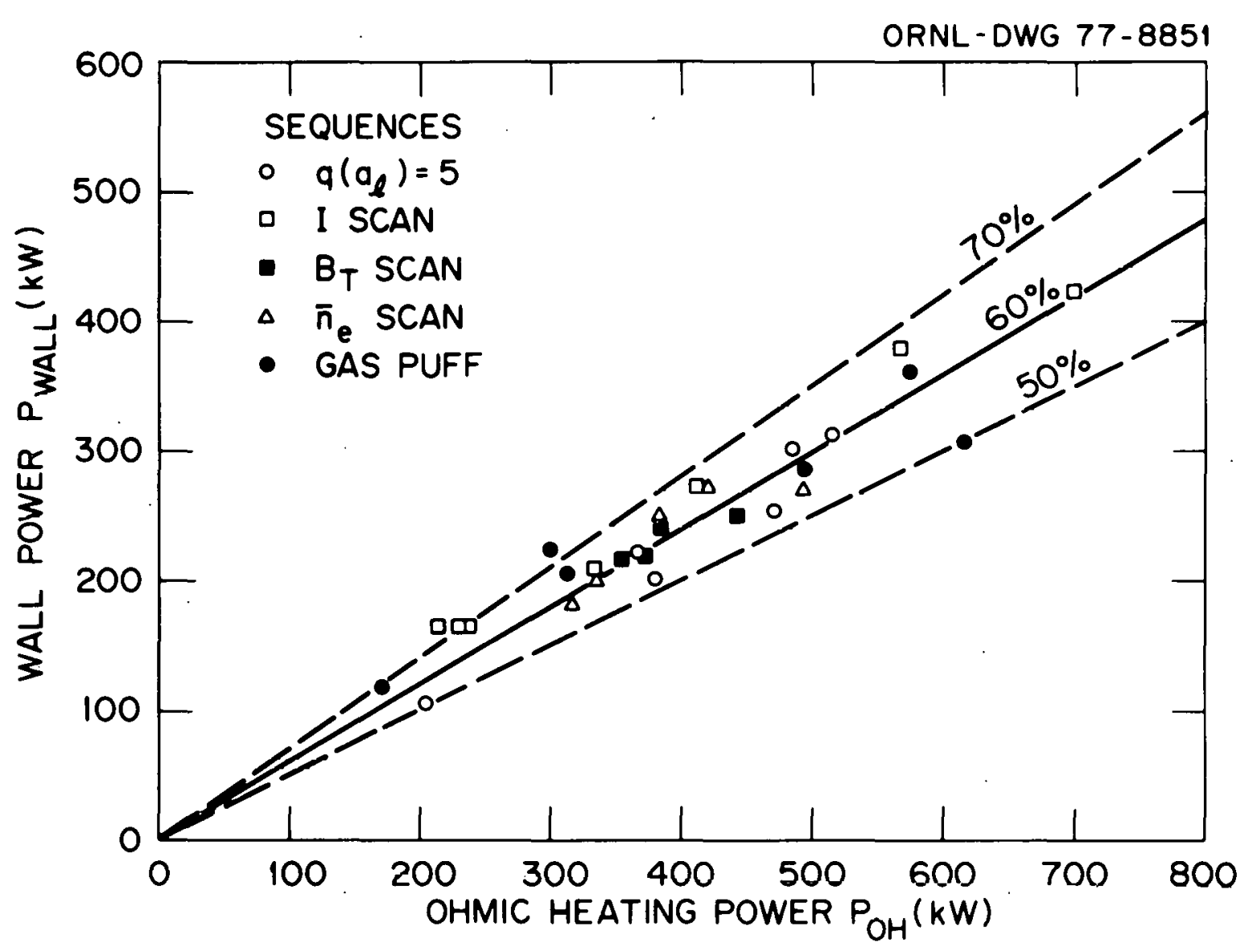

Fig. 5 


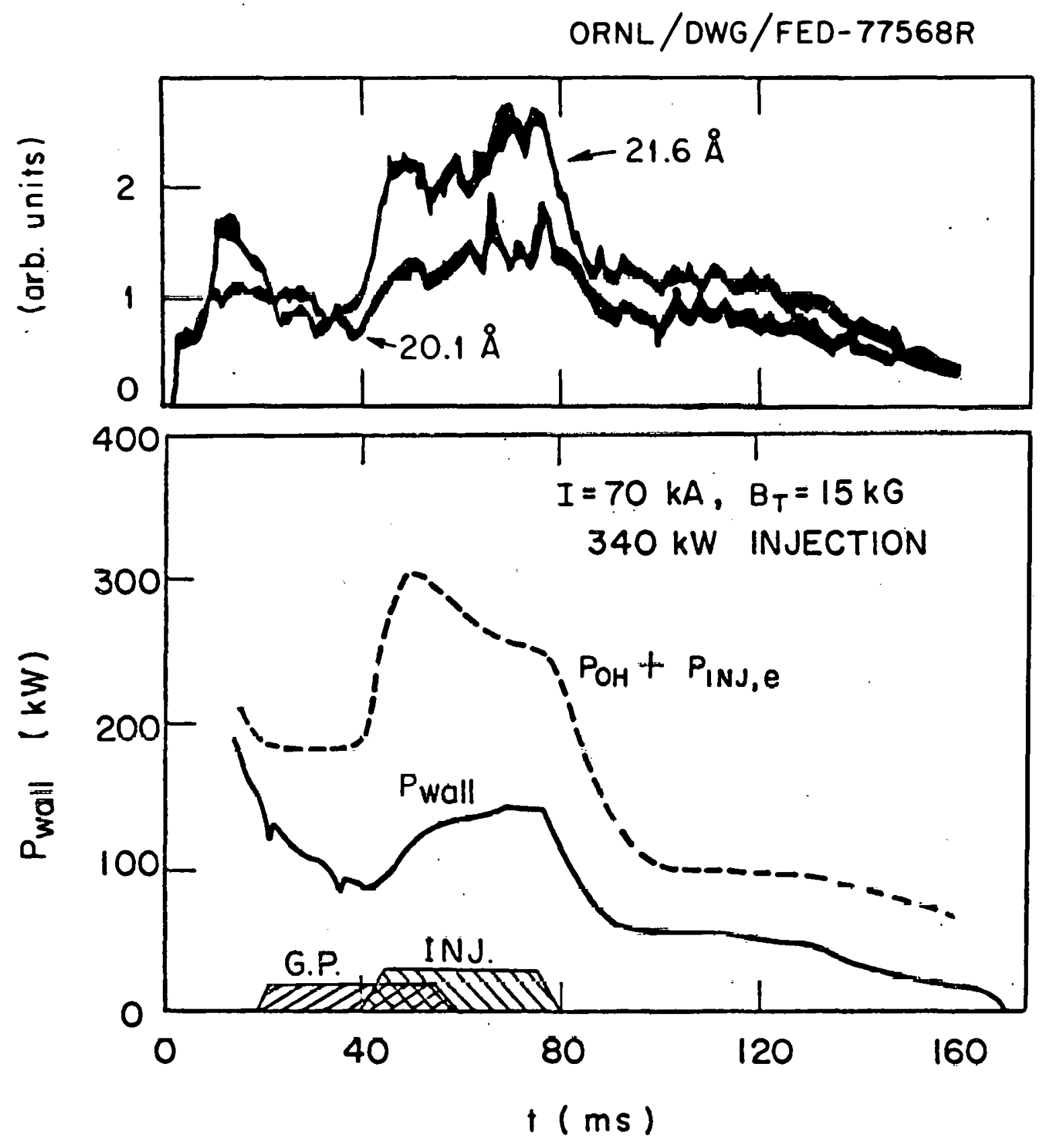

Fig. 6 


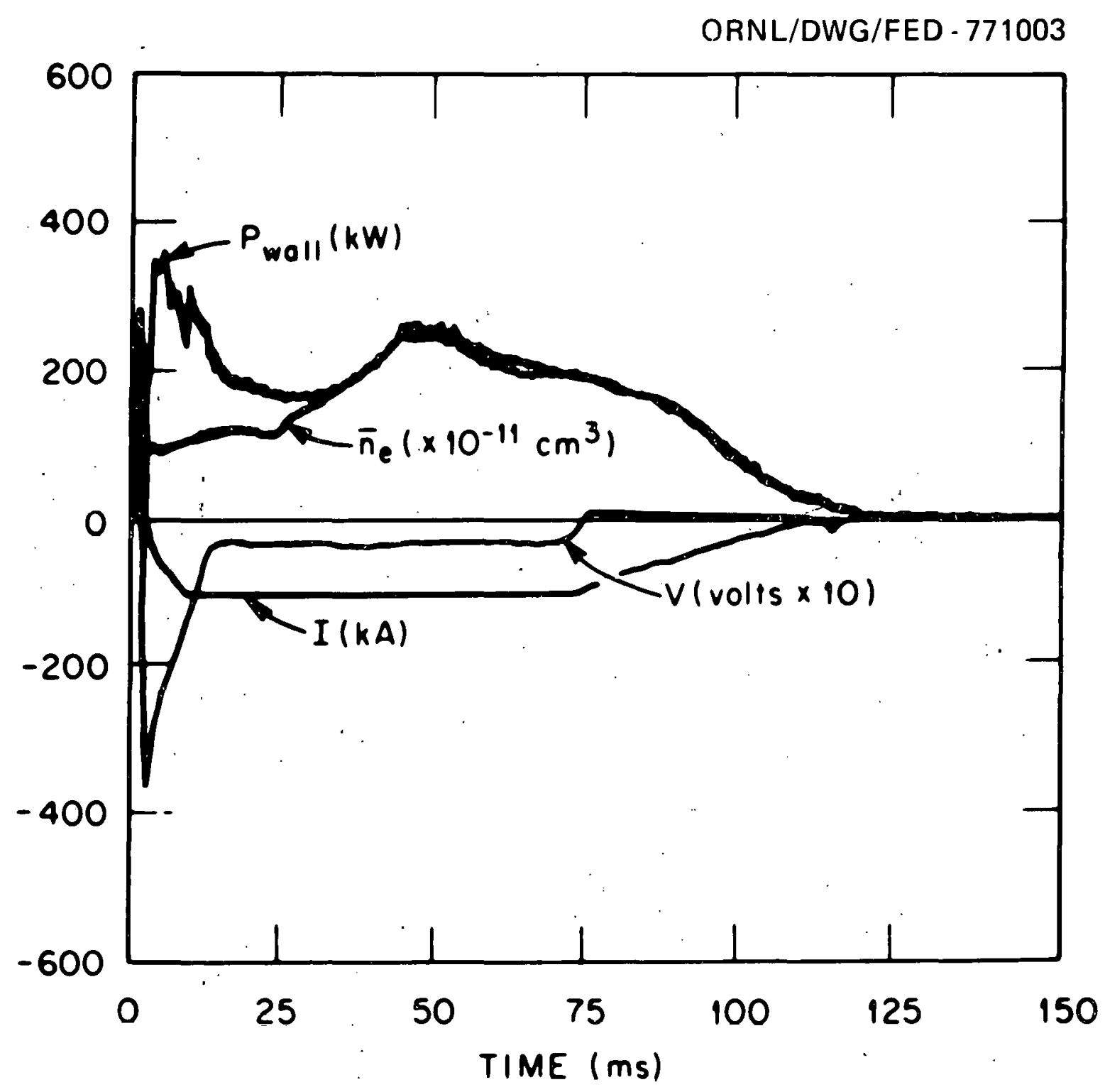

Fig. 7 
ORNL / DWG / FED - 77567

$\mathrm{I}=175 \mathrm{kA}, \mathrm{B}_{\mathrm{T}}=26 \mathrm{kG}$

( 350 kW-INJ. ) + (GAS PUFF)
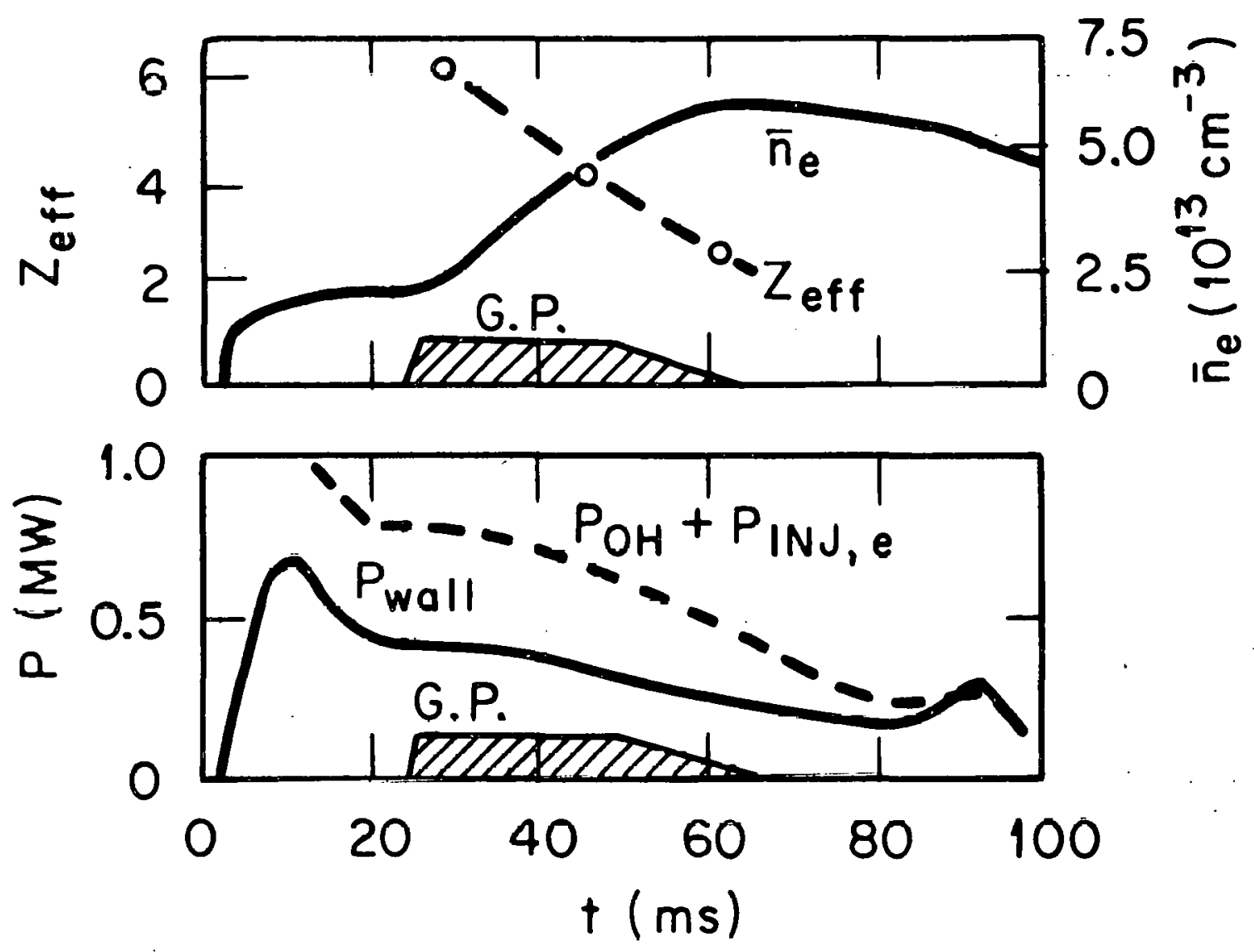

Fig. 8 


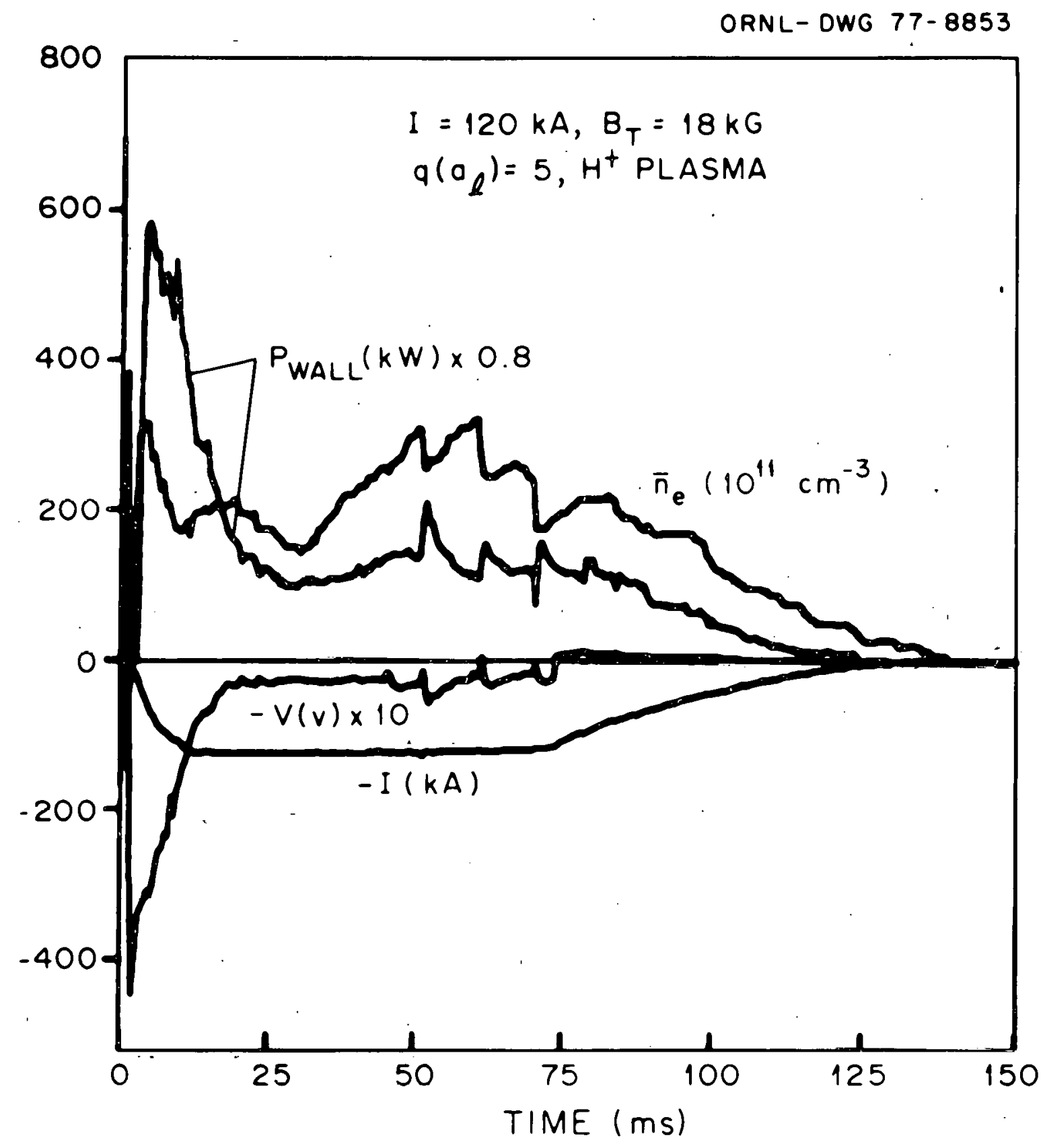

Fig. 9 
34

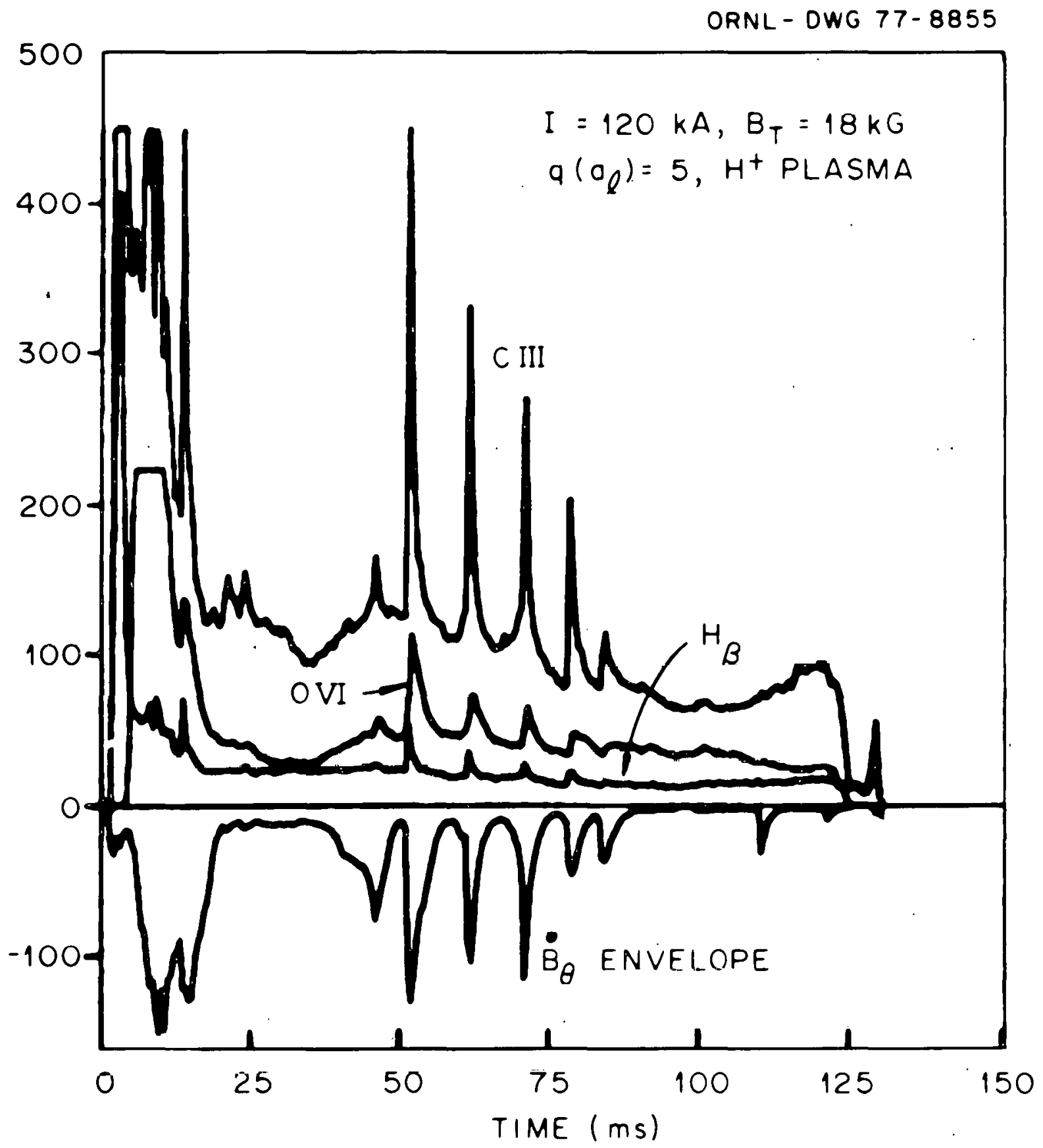

Fig. 10 , 


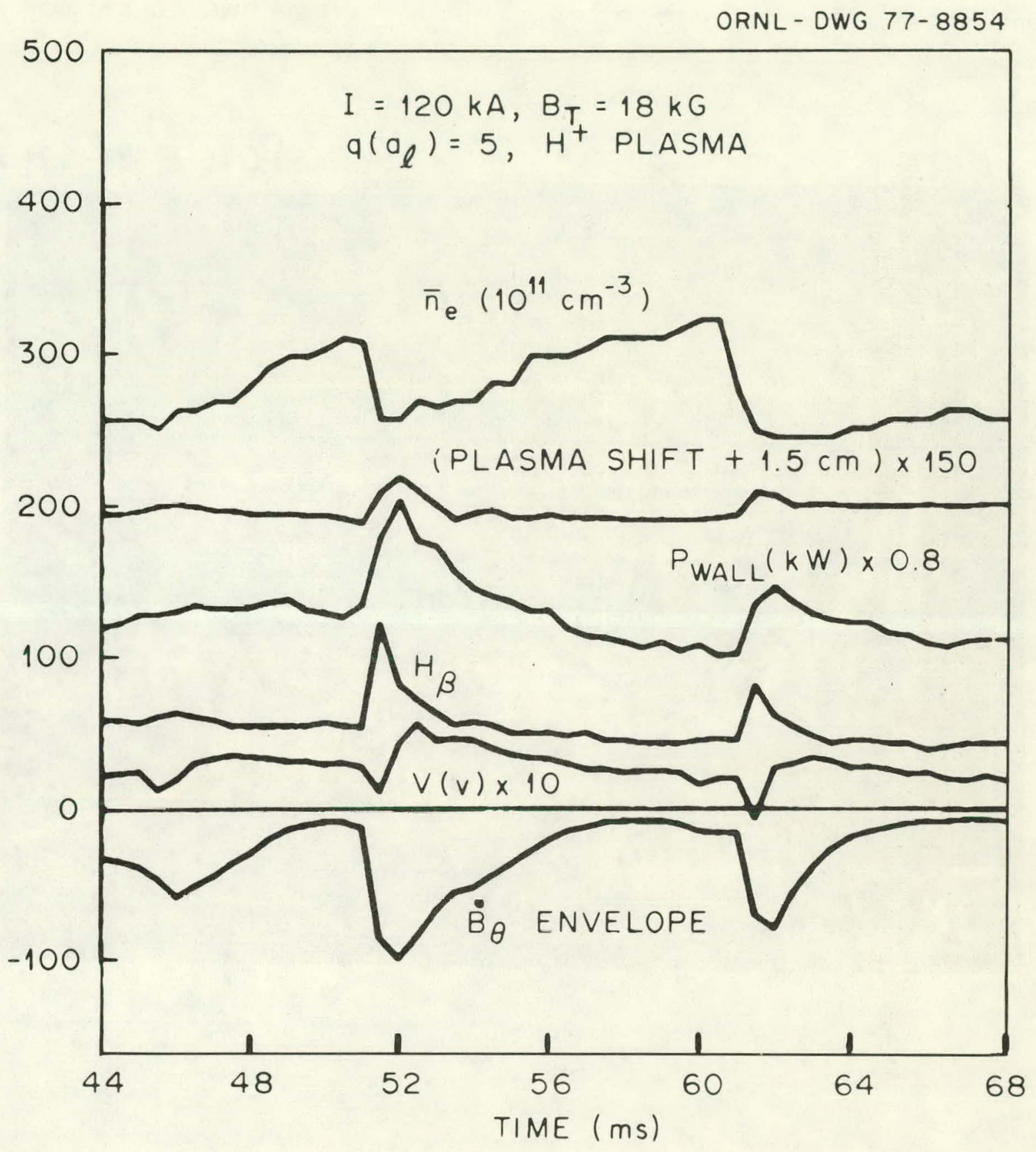

Fig. 11 


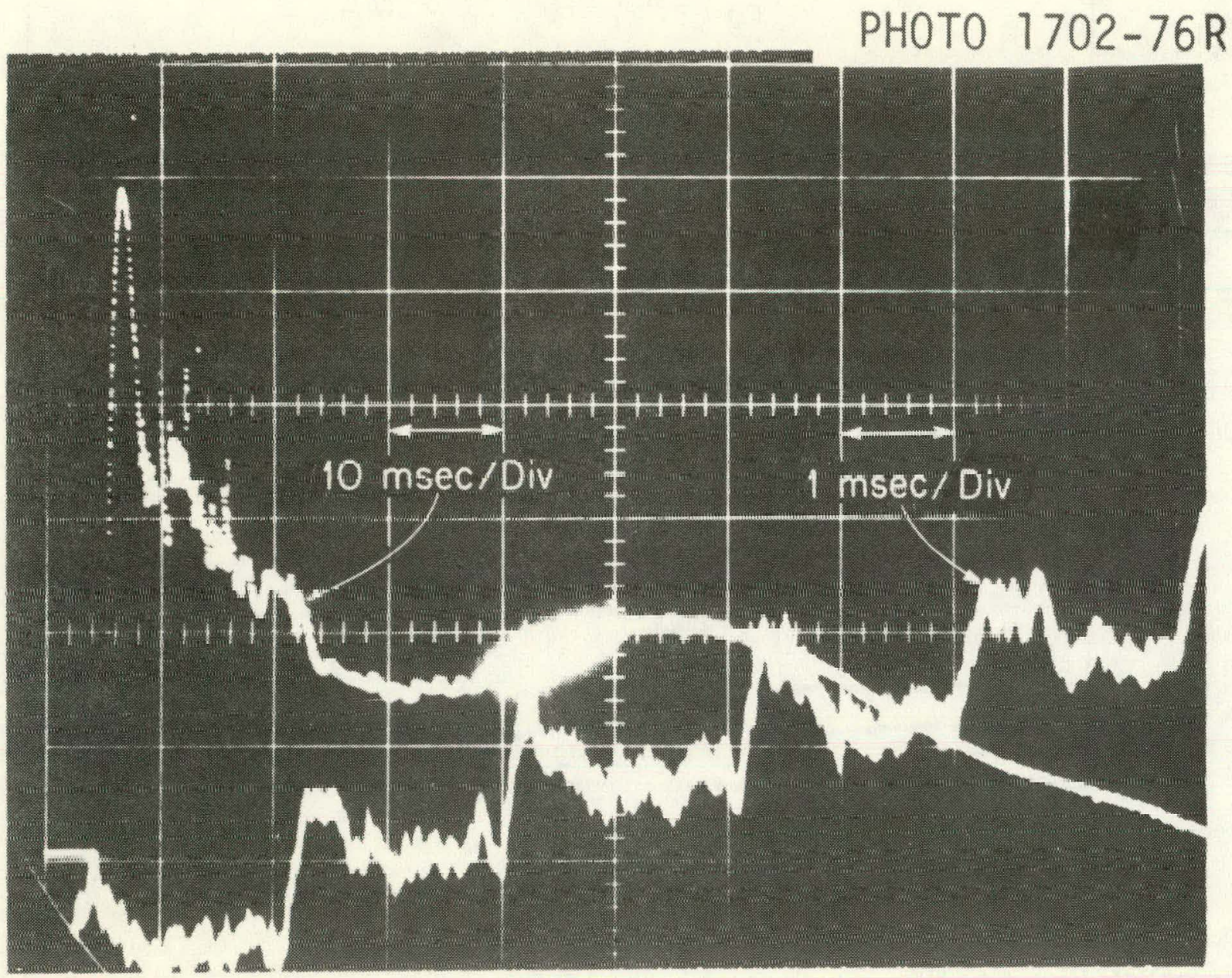

Fig. 12 


\section{INTERNAL DISTRIBUTION}

$\begin{aligned} \text { 1. } & \text { C. F. Barnett } \\ \text { 2. } & \text { L. A. Berry } \\ 3 . & \text { K. Burrell } \\ \text { 4-18. } & \text { C. E. Bush } \\ \text { 19. } & \text { J. D. Callen } \\ 20 . & \text { R. J. Colchin } \\ \text { 21. } & \text { R. A. Dand1 } \\ 22 . & \text { J. L. Dunlap } \\ 23 . & \text { G. R. Dyer } \\ 24 . & \text { P. H. Edmonds } \\ 25 . & \text { A. C. England } \\ 26 . & \text { J. T. Hogan } \\ 27 . & \text { K. W. Hill } \\ 28 . & \text { H. C. Howe } \\ 29 . & \text { R. C. Isler } \\ 30 . & \text { T. C. Jernigan } \\ 31 . & \text { G. G. Kelley } \\ 32 . & \text { P. W. King } \\ 33 . & \text { J. F. Lyon }\end{aligned}$

34. J. R. McNa11y, Jr.

35. D. H. McNeill

36. O. B. Morgan

37. M. Murakam1

38. G. H. Neilson

39. W. Namkung

40. H. Postma

41. J. A. Rome

42. M. W. Rosenthal

43. D. W. Swain

44. J. B. Wilgen

45-46. Central Research Library

47. Document Reference Section

48-49. Fusion Energy Division Library

50. Fusion Energy Division Reports Office

51-52. Laboratory Records Department

53. Laboratory Records - ORNL-RC

54. ORNL Patent Office

\section{EXTERNAL DISTRIBUTION}

55. V. V. Alikaev, Kurchatov Institute, Moscow, U.S.S.R.

56. C. M. Braams, Fom-Instituut voor Plasma-Fysica, Rijnhuizen, Jutphaas, The Netherlands

57. A. M. Budker, Nuclear Physics Institute, Siberian Academy of Sciences, Novosibirsk 90, U.S.S.R.

58. P. Caldirola, Laboratorio di Fisica del Plasma ed Elettronica Quantistica del C.N.R., Via Celoria 16, 20133 Milano, Italy

59. Center for Plasma Physics and Thermonuclear Research, University of Texas, Physics Bldg. 330, Austin, TX 78712

60. J. F. Clarke, Division of Magnetic Fusion Energy, Department of Energy, Washington, DC 20545

61. T. Consoli, Centre d'Etudes Nucleaires de Grenoble, Avenue des Martyrs 38, Grenoble, France

62. N. A. Davies, Tokamak Branch, Division of Magnetic Fusion Energy, Department of Energy, Washington, DC 20545

63. S. 0. Dean, Office of Confinement Systems, Division of Magnetic Fusion Energy, Department of Energy, Washington, DC 20545

64. Director, Technical Library, Defense Atomic Support Agency, Sandia Base, Albuquerque, NM 87115

65. D. Dimock, Princeton Plasma Physics Laboratory, Princeton University, P.0. Box 451, Princeton, NJ 08540

66. A. M. Dupas, Documentation S.I.G.N., Department de la Physique du Plasma et de la Fusion Controlée, Association Euratom-CEA sur la Fusion, Centre d'Etudes Nucleaires, B.P. 85, Centre du Tri, Grenoble, France 
67. R. A. E11is, Princeton Plasma Physics Laboratory, Princeton University, P.0. Box 451, Princeton, NJ 08540

68. G. A. Emmert, Department of Nuclear Engineering, University of Wisconsin, Madison, WI 53706

69. H. K. Forsen, Exxon Nuclear Company, Inc., 777 106 th Avenue, NE, Bellevue, WA 98004

70. T. K. Fowler, University of California, Lawrence Radiation Laboratory, Livermore, CA 94551

71. M. Fujiwara, Insitute of Plasma Physics, Nagoya University, Nagoya, Japan

72. Fusion Research Program Library, 153 Engineering Research Bldg., 1500 Johnson Avenue, Madison, WI 53706

73. P. Ginot, DPh-PFC/Service du Confinement des Plasmas, Centre d'etudes Nucleaires, B.P. 6, 92260 Fontenay-aux-Roses, France

74. W. C. Guss, General Atomic Company, P.0. Box 81608, San Diego, CA 92138

75. A. M. Hamende, International Centre for Theoretical Physics, Trieste, Italy

76. R. L. Hirsch, Science and Technology Department, Exxon Corporation, 1251 Avenue of The Americas, New York, NY 10020

77. P. Hubert, Service de Recherches sur la Fusion Controlée, Centre d'Etudes Nucleaires, Fontenay-aux-Roses, France

78. J. Hugill, Culham Laboratory, Abingdon, Oxon, 0X14 3DB, England

79. T. Hsu, Office of Confinement Systems, Division of Magnetic Fusion Energy, Department of Energy, Washington, DC 20545

80. H. C. S. Hsuan, Princeton Plasma Physics Laboratory, Princeton University, P.0. Box 451, Princeton, NJ 08540

81. H. Ikegami, Nagoya University, Nagoya, Japan

82. 0 . Klüber, Max-Planck-Institut für Plasmaphysik, 8046 Garching bei München, Federal Republic of Germany

83. H. E. Knoepfe1, Laboratorio Gas Ionizzati, C.P. 65, 00444 Frascati (Roma), Italy

84. Library, Centre de Recherches en Physique des Plasmas, 21 Avenue des Bains, 1007 Lausanne, Switzerland

85. Librarian, Max-Planck-Institut für Plasmaphysik, 8046 Garching bei München, Federal Republic of Germany

86. Librarian, Culham Laboratory, Abingdon, Oxon, OX14 3DB, England

87. S. Matsuda, Thermonuclear Fusion Laboratory, Japan Atomic Energy Research Institute, Tokai, Ibaraki, Japan

88. S. V. Mirnov, Thermonuclear Laboratory, Kurchatov Institute, Moscow, U.S.S.R.

89. V. S. Mukhavatov, Thermonuclear Laboratory, Kurchatov Institute, Moscow, U.S.S.R.

90. T. Ohkawa, General Atomic Company, P.0. Box 81608, San Diego, CA 92138

91. D. Palumbo, Directorate General for Research and Training, Euratom, 51 Rue Belliard, Brussels 5, Belgium

92. J. W. M. Pau1, Culham Laboratory, Abingdon, Oxon, OX14 3DB, England

93. R. S. Pease, Culham Laboratory, Abingdon, Oxon, 0X14 3DB, England

94. Plasma Laboratory Reading Room, Room 20A-222, Massachusetts Institute of Technology, Cambridge, MA 02139 
95. F. Prevot, Chef du Service du Confinement des Plasmas, B.P. 6, Fontenay-aux-Roses, France

96. D. H. Priester, Division of Magnetic Fusion Energy, Department of Energy, Washington, DC 20545

97. M. S. Rabinovich, Lebedev Institute of Physics, Academy of Sclences of the U.S.S.R., Leninsky Prospect 53, Moscow, U.S.S.R.

98. Research and Technical Support Division, Department of EnergyOak Ridge Operations, P.O. Box E, Oak Ridge, TN 37830

99. D. J. Rose, Massachusetts Institute of Technology, Cambridge, MA 02139

100. L. Scaturo, Massachusetts Institute of Technology, Cambridge, MA 02139

101. P. Smeulders, Max-Planck-Institut für Plasmaphysik, 8046 Garching bei München, Federal Republic of Germany

102. L. D. Smullin, Massachusetts Institute of Technology, Cambridge, MA 02139

103. C. Spight, Physics Department, Morehouse College, Atlanta, GA 30314

104. J. Tachon, DPh-PFC/Service du Confinement des Plasmas, Centre d'Etudes Nucleaires, B.P. 6, Fontenay-aux-Roses, France

105. T. Uchida, Department of Nuclear Engineering, Faculty of Engineering, University of Tokyo, 3-1, Hongo, Bunkyo, Tokyo, Japan

106. S. Yoshikawa, Princeton Plasma Physics Laboratory, Princeton University, P.0. Box 451, Princeton, NJ 08540

107. S. J. Zweben, Center for Plasma. Physics and Fusion Engineering, University of California, Los Angeles, CA 90024

108-296. Given given distribution as shown in TID-4500, Magnetic Fusion Energy 